\title{
Payments for Watershed Protection Services: Emerging Lessons from the Philippines
}

\author{
Daniel Gaitán Cremaschi ${ }^{1}$, Rodel D. Lasco ${ }^{1,2,3} \&$ Rafaela Jane P. Delfino ${ }^{1}$ \\ ${ }^{1}$ World Agroforestry Centre (ICRAF), Philippines \\ ${ }^{2}$ University of the Philippines at Los Baños, Philippines \\ ${ }^{3}$ Oscar M. Lopez Center for Climate Change Adaptation and Disaster Risk Management, Manila, Philippines \\ Correspondence: Daniel Gaitán Cremaschi, P/A Hollandseweg 1, Lst gr BEC, 6706 KN, Wageningen, the \\ Netherlands. E-mail: dagacremaschi@gmail.com \\ Rodel D. Lasco, World Agroforestry Centre (ICRAF) Philippines, $2^{\text {nd }}$ Floor, Khush Hall, IRRI Campus, College, \\ 4031 Laguna, Philippines. E-mail: r.lasco@cgiar.org
}

Received: August 8, 2012 Accepted: December 7, 2012 Online Published: December 31, 2012

doi:10.5539/jsd.v6n1p90 URL: http://dx.doi.org/10.5539/jsd.v6n1p90

\begin{abstract}
There is growing interest on payments for ecosystem services (PES) in developing countries including the Philippines. Watersheds have been degraded through deforestation and subsequent conversion to other land cover, principally for agriculture. In the last decade, several Payments for Watershed Services schemes have been implemented and this paper is an attempt to assess the form of incentives or rewards that have been provided to upland communities in a number of sites under different management leadership in the Philippines. We reviewed four cases specifically related to watershed services in the: 1) Bakun Watershed, 2) Maasin Watershed, 3) Sibuyan Watershed, and 4) Baticulan Watershed. The case studies of varying stages of implementation has shown that the chances of success of PES schemes in promoting watershed conservation and rehabilitation as well as in improving the livelihoods of upland communities is constrained by incomplete information and knowledge about the interaction between ecosystem properties and provision of services, and the difficulty in establishing voluntary participation and conditionality of payments. In this paper, we argued that institutions may enable or hinder the successful implementation of PES. The role of the local government as intermediaries is crucial in the process of establishing PES more particularly in the information dissemination and education of the key stakeholders. The case studies also showed how PES programs are reinforced by the presence of non-government organizations.
\end{abstract}

Keywords: payments for ecosystem services (PES), watershed protection services, Philippines, additionality

\section{Introduction}

Natural areas are sources of a range of ecosystem services that benefit stakeholders on the local, national and international level (International Union for Conservation in Nature [IUCN], 2000). In economic terms, ecosystem services can be seen as positive externalities, benefits that people obtain directly or indirectly from the environment for free and therefore are not included or internalised in the market (Kosoy \& Corbera, 2010).

In spite of the many services provided by nature ecosystems are being degraded affecting over $60 \%$ of ecosystem services, which have threatened the natural environment society and human well-being (Millennium Ecosystem Assessment [MA], 2005). The degradation of natural capital is a consequence of the conversion of natural systems for other uses, loss of connectivity between different habitats, overexploitation of natural resources, pollution generated by human activities and loss of biodiversity (MA, 2005). The degradation of the environment has been exacerbated by market failures, lack of information with regard to the characteristics of various ecosystem services and to the existence of perverse subsidies and taxes which encourage activities that are not in harmony with the environment (Turner et al., 2000; Balmford et al., 2002; Kosoy \& Corbera, 2010; de Groot et al., 2007; Kosoy et al., 2007).

Watersheds have been highly affected in environmental degradation. Despite the ecosystem services provided, which are essential for the livelihood mainly of poor rural communities, human pressures on the environment have threatened their ecological integrity. Governments and non-governmental institutions have historically 
made several attempts to maintain watershed services, but most of them, based on command and control mechanisms, have failed due to the top-down approach of their implementation, the limited involvement of communities, and the lack of monetary resources (Alpízar \& Madrigal, 2008).

In the case of the Philippines, the situation has not been different. About $70 \%$ of the country's total land area consists of watersheds (Arocena-Francisco, 2002) which in the past were mostly covered by forest. However, in the last 60 years the high deforestation rate of about 100000 hectares per year, a consequence of logging activities, conversion to agricultural lands and settlements, have reduced the flow of watershed services (Bennagen et al., 2006; Arocena-Francisco, 2002). In response, the government has adopted community-based forest management and watershed management approaches (Chokkalingam et al., 2006). In addition, there is a growing interest in PES mechanisms in the Philippines as can be seen in several attempts to promote rewards and payments for ecosystems services such as water and carbon (Villamor \& Lasco, 2009; Lasco et al., 2010). A national technical working group meets regularly and two major national conferences have been held to look into experiences, lessons learned, policy implications, and research needs for PES (Padilla et al., 2006).

According to neoclassical economic assumptions, the PES scheme is based on the principle that people located in places of great importance for the provision of services (providers) are compensated for maintaining and securing its provision and those who receive the benefits from the environment should pay for its protection (Wunder, 2005; Pagiola et al., 2005; Engel et al., 2008). In this order of ideas, the beneficiaries or potential buyers of ecosystem services, make a voluntary contract with land managers to compensate the switch to another land use. Taking into account that the benefits that land managers/service providers obtain from ecosystem services are often lower than those they would obtain from intensive land use, a bargaining process should be undertaken. At the bargaining process the beneficiaries/buyers should at least compensate the opportunity cost of land or the providers would not be willing to accept. Furthermore, the maximum amount of money paid by the beneficiaries should be less than the value of the benefits they would obtain for the protection, conservation and provision of ecosystem services or they would not be willing to pay (Wunder, 2005; Engel et al., 2008).

According to Wunder (2005) the definition of PES includes five main characteristics: 1) There must be a voluntary transaction between providers and buyers, 2) the ecosystem service which is traded should be clearly defined and measurable, 3) the ecosystem service is demanded by buyers, 4) its provision and conservation is carried out by providers, and finally 5) the payment should be made only with the condition that the provider secure the flow of the ecosystem service through time, namely additionality must be proved.

This paper is an attempt to assess the success factors and constraints in the forms of incentives or rewards that have been provided to upland communities in selected sites under different management leadership in the Philippines. This will help fulfill the gaps in developing the most appropriate mechanism to enhance the benefits of current and new PES schemes. Thus, the paper provides a review and synthesis of the information on the rationale and issues in existing payment mechanism for ecosystem services from four case studies of watershed protection service schemes. The design of each of the PES experience is described looking at the (1) local conditions and the driving factors that led to the development of PES, (2) the stakeholders involved in PES design (sellers, buyers, and intermediaries) including their roles and the institutional arrangements and (3) the payment scheme or mechanisms in providing environmental incentives. It also discusses the relevant factors in attaining the environmental goals for which they were created. Finally, some lessons are drawn that might be taken into account in the formulation of new schemes in the Philippines and other developing countries. The results are most useful to the local governments, water districts, communities and other stakeholders that may wish to explore PES mechanism as a strategy for watershed management.

\section{Philippine Experiences on Payment for Watershed Services}

The following section describes actual experiences of PES in the Philippines (Figure 1), specifically related to watershed services in the: 1) Bakun Watershed, 2) Maasin Watershed, 3) Sibuyan Watershed, and 4) Baticulan Watershed.

\subsection{The Bakun Watershed}

\subsubsection{Local Conditions and Driving Factors for PES Schemes}

The Bakun watershed is located in the province of Benguet in the Northern Philippines (World Agroforestry Centre [ICRAF], 2006). It has approximately a total area of $310 \mathrm{~km}^{2}$ which is divided in seven barangays (village) (Swallow et al., 2010). The topography of Bakun varies from gentle to steep slopes. The watershed provide many ecosystem services such as water flow regulation, beautiful landscapes, spiritual enhancement, water for domestic consumption, water supply for industrial purposes (hydroelectric production), irrigation water 
for several lowland and upland crops (specially rice fields, indigenous crops and vegetables), sediment control, optimal habitat for different species, food, timber, and more (ICRAF, 2006; ICRAF, 2007). In spite of the importance of forests for society, in past years Bakun has experienced a high deforestation rate. Forested land has been rapidly converted into agricultural fields, affecting the provision of some ecosystem services.

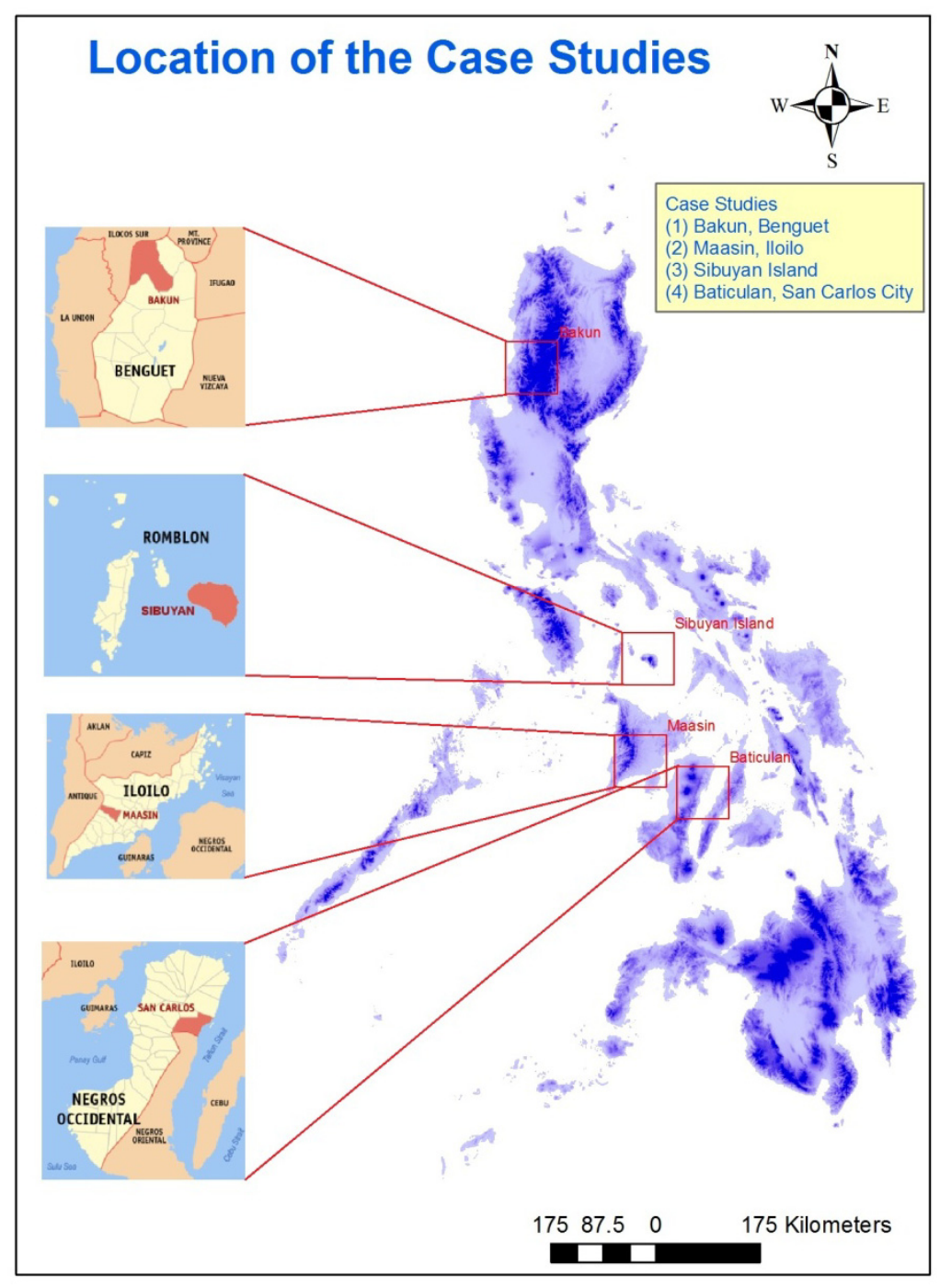

Figure 1. Map showing the location of the case studies

\subsubsection{Stakeholders (Sellers, Buyers and Intermediaries) and Institutional Arrangements}

The service providers are the Bago and Kankana-ey indigenous groups, comprising almost $92 \%$ of the total population and have shaped the history of Bakun watershed. The indigenous people are predominantly poor and have limited economic activities (Villamor \& Lasco, 2006). Most of them are involved in subsistence agriculture as they lack the educational qualifications for employment in the public and private sector (ICRAF, 2006). In spite of their economic condition, their traditional ecological knowledge explains how they relate to the natural world. Sustainable farming and land management practices are commonly implemented to maintain the provision of watershed services (Swallow et al., 2010; ICRAF, 2007).

Although watershed services benefit several scales of stakeholders, the two hydropower companies are thought to be the main beneficiaries from the conservation of watershed. Out of four rivers in Bakun, two are used to support the operation of the Hydroelectric Development Corporation (HEDCOR, Inc.), the Northern MiniHydro Corporation, and the Luzon Hydropower Corporation (LHC) (Villamor \& Lasco, 2009). 


\subsubsection{Payment Schemes}

As mandated by the Energy Act of 1992 and the Electric Power Industry Reform Act of 2001, HEDCOR and LHC have formalized separate Memorandum of Agreements (MOAs) with the local governmental unit (LGU) of Bakun. In the MOAs, the duties and responsibilities of both parties were stipulated, as well as the amount to be paid to the host municipality for the use of the water domain. Money is collected in the form of an Electrification Fund, namely $50 \%$ of one centavo per kilowatt-hour of total electricity sales; Development and Livelihood Fund, namely $25 \%$ of one centavo per kilowatt-hour; and Reforestation, Watershed Management, Health and/or Environmental Enhancement Fund, namely 25\% of one centavo per kilowatt-hour of the total electricity sales (Leimona et al., 2007). Statutory benefits in terms of tax payments are also paid directly or indirectly to the local government to be shared in the province, municipality and barangays (Leimona et al., 2007; Villamor et al., 2007). Finally, the companies share a percentage of the total electricity sales for social development and livelihood assistance and for infrastructure projects such as roads and bridges (Villamor et al., 2007). According to ICRAF (2006), from the time the payments started, the economic resources of the municipalities have significantly increased. However, "payments or rewards" have not often been allocated for watershed protection and it is unclear how much money the indigenous communities are receiving for the maintenance of the natural environment.

The IFAD-supported rewarding the Upland Poor for Environmental Services (RUPES) programme of ICRAF is a key catalyst in promoting PES in the watershed. Through constant training, the RUPES programme has informed different stakeholders about the nature of the RUPES and how it could improve the livelihood of local communities. The support of RUPES has been key in the successful negotiation of in-kind payments, which include electricity to some villages, scholarships for local students, farmer trainings in tree planting, construction of roads, and more (Swallow et al., 2010). Although voluntary benefits have improved economic development, these benefits are not currently conditioned in service provision, which creates an obstacle for the short and long-term implementation of the programme. Consequently, RUPES continues to work together with different stakeholders to develop effective and transparent market-based mechanisms that will enhance livelihoods, reduce poverty and support the conservation of natural capital (Villamor \& Lasco, 2009).

\subsection{The Maasin Watershed}

\subsubsection{Local Conditions and Driving Factors for PES Schemes}

The Maasin Watershed project was one of the first places where a PES scheme was implemented in the Philippines (Salas, 2005). The Maasin watershed, located 30 kilometres from Iloilo City, has an area of 6738 hectares covering three municipalities, sixteen barangays and eighty sitios (Arocena-Francisco, 2002). The area is composed of brushlands, forest vegetation, rice fields and other agricultural land (Francisco \& Rola, 2004). Maasin regulates the impacts of extreme weather events, thus reducing the occurrence of flooding. The land cover in the watershed regulates the water flowing through the rivers, controls the rates of recharge and discharge from the aquifer, and provides natural resources such as branches, firewood, herbs and fibres to upland communities (Table 1).

Because the Maasin watershed is the main source of water for Iloilo City, it was declared a reserved area in 1923. Historically, it has been managed by different governmental institutions such as the Department of Environment and Natural Resources (DENR), the Metro Iloilo Water District (MIWD) and the local government. These governmental institutions are responsible for maintaining the dynamics of the watershed to secure the provision of ecosystem services (Salas, 2005).

\subsubsection{Stakeholders (Sellers, Buyers and Intermediaries) and Institutional Arrangements}

Different stakeholders have acted as the service providers and the beneficiaries of the ecosystem services. The service providers have changed according to the political and institutional context in which the Maasin area had been managed. Currently, some of the most influential service providers are the upland communities living in the watershed. Most of them are engaged in farming within the reserve, highly influencing the provision of ecosystem services by the watershed (Francisco \& Rola, 2004). 
Table 1. Watershed ecosystem services in the Maasin Watershed (adapted from Salas, 2004)

\begin{tabular}{ll}
\hline Provisioning Services & $\begin{array}{l}\text { Supply of water for domestic use, for irrigation and industrial } \\
\text { purposes } \\
\text { Gathering of fish, game, fruits, medicinal plants and small scale } \\
\text { subsistence farming } \\
\text { Material used by local inhabitants for construction and fuel (wood, } \\
\text { fibre, etc.) }\end{array}$ \\
Raw materials & Flood control and storm protection \\
\hline Regulation services & Capturing of dust, chemicals and other elements by the land cover of \\
weather events & the watershed \\
Air quality regulation & Prevention of damage from erosion/siltation \\
Erosion prevention & Enjoyment of a pleasant environment \\
\hline Cultural \& Amenity services & Folklore, life stories, anecdotes, socio-cultural values and norms \\
\hline Aesthetic information &
\end{tabular}

On the other hand, people reap varying benefits from the ecosystem services according to the scale on which they operate. They are catalogued as potential buyers because their livelihood is determined by continuous watershed ecosystem services. About 500000 residents of Iloilo City and about 2000 households along the watershed demanded water from the rivers (Francisco \& Rola, 2004). Small industries, businesses and farmers also used the river water (Salas, 2005).

Unfortunately, high deforestation rates in the past 30 years pose serious problems to approximately ten thousand inhabitants whose livelihoods depend on ecosystem services in Maasin (Salas, 2005). Loss of forest cover results in a lower quantity of water flowing through the watershed. Only $35 \%$ of the water demand of Iloilo City was met (Salas, 2005; Porras \& Neves, 2006). Likewise, the incidence of floods increased and a shortage of irrigation water occurred during the summer season (Arocena-Francisco, 2002; Porras \& Neves, 2006).

\subsubsection{Payment Schemes}

After continued debate, different strategies were proposed. One was to ask the MIWD to pay the upland communities for the efforts to conserve the watershed (Salas, 2005). Because Iloilo City experienced a water crisis in the 1990s, the local government, based on the Republic Act 7160, also known as the Local Government Code of 1991, demanded MIWD to pay real estate tax and 1 per cent user's fee for watershed protection (Arocena-Francisco, 2002). Until 1995 the payment was made to the local government. Money was then transferred by MIWD to the Iloilo Watershed Management Council (IWMC), a multi-sectoral body created in 2000, responsible for the conservation, development, protection, and utilization of the 15 watersheds in the Province of Iloilo (Francisco \& Rola, 2004).

The funding from different sources, including user fees from MIWD, sporadic voluntary donations, and a loan given by the Japanese Bank for International Cooperation, represented a significant amount of money to reforest the Maasin Watershed (Porras \& Neves, 2006). Communities comprising the People's Organization Federations (KAPAWA) were paid to reforest with Gmelina trees, fruit trees, bamboo and coffee, and were asked to take care of the trees. Their compensation was $70 \%$ share of the revenues gained from the by-products of the trees planted for the entire duration of the reforestation contract, which was for 25 years (Salas, 2005). Communities were also contracted to undertake natural regeneration, technically assisted by DENR (Arocena-Francisco, 2002). DENR supported the building capacity of upland communities and the cooperative endeavours of the members. These efforts helped create several social organizations that were merged into the KAPAWA (Francisco \& Rola, 2004). Subsequently, the vegetative land cover seemed to indicate land rehabilitation in the Maasin watershed (Francisco \& Rola, 2004). According to Porras and Neves (2006), 2742 hectares were reforested and established with agroforestry and several riverbank areas were stabilized. Additionally, protective infrastructures, trails, line fires, nurseries, concrete dams and lookout towers were supported (Porras \& Neves, 2006). 
In spite of the benefits, after two years the MIWD stopped the transfer of additional money to the DENR, because it was not clear if the money was being channelled directly to the service providers (Salas, 2005). In 2002, three years after project implementation, the water level in the rivers in the dry season was low, despite the assertion of the DENR that the trees would give more water (Porras \& Neves, 2006). Additionally, upland communities were not happy with the outcome of the watershed rehabilitation projects. Instead of receiving payment from the users of water, communities were "rewarded" with labour's wages for reforestation and land rehabilitation. Furthermore, the species that were planted did not increase their food security and thus they had to look for other jobs to increase their income (Salas, 2005). These are the main reasons why payment was not sustained.

\subsection{Sibuyan Island: Cantingas and Panangcalan Watersheds}

\subsubsection{Local Conditions and Driving Factors for PES Schemes}

Sibuyan Island is located in the centre of the Philippine Archipelago about $350 \mathrm{~km}$ south of Manila (World Wildlife Fund (WWF)/Philippines, n.d.). The island is one of the richest areas in biodiversity in the world, hosting around 60 endemic species and several species of flora and fauna (WWF, 2006; DENR, 1997 in Villamor \& Lasco, 2009). The inhabitants of the upland areas of Mt. Guiting-guiting comprise the Mangyan Tagabukid, an indigenous tribe that has a close relationship with the land (WWF/Philippines, n.d.). The Mangyan Tagabukid depends in a great extent in the natural resources delivered by Mt. Guiting-Guiting (Villamor \& Lasco, 2009).

Two important watersheds in the Sibuyan Island are the Cantingas and Panangcalan. The Cantingas watershed has a length of approximately $17 \mathrm{~km}$ and drains an area of about $48 \mathrm{~km}^{2}$. Both watersheds provide ecosystem services that benefit stakeholders in the upland and lowland areas as enumerated in Table 2. These services include flood mitigation, water flow regulation, water supply (irrigation and urban consumption), protection of the soil structure and therefore reduction of soil erosion, habitat for several species of flora and fauna, water for hydropower production and recreation (Villamor \& Lasco, 2009).

The most important ecosystem services for local inhabitants are the mitigation of extreme floods and the supply of clean water for urban and agricultural purposes (Villamor \& Lasco, 2009). The degradation of the two watersheds in past years has led to the creation of the WWF-CARE Equitable Payments for Watershed Services (EPWS) project. The WWF-CARE EPWS project focused on the Cantingas and Panangcalan watersheds.

Table 2. Cantingas and Panangcalan Watershed Services (WWF/Philippines, n.d.)

\begin{tabular}{|c|c|c|}
\hline Services & Cantingas Watershed & Panangcalan Watershed \\
\hline \multicolumn{3}{|l|}{ Provisioning Services } \\
\hline Water & $\begin{array}{l}\text { Use of water for drinking and washing } \\
\text { Wells in lowland areas are recharged by } \\
\text { Cantingas River } \\
\text { Habitat for edible fresh aquatic organisms }\end{array}$ & $\begin{array}{l}\text { Supply of drinking water for San Fernando } \\
\text { Wells in lowland areas are recharged by } \\
\text { Cantingas River } \\
\text { Habitat for edible fresh aquatic organisms }\end{array}$ \\
\hline \multicolumn{3}{|l|}{ Regulating Services } \\
\hline Flood mitigation & $\begin{array}{l}\text { The characteristics of the watershed and its } \\
\text { forest cover reduce runoff and the incidence } \\
\text { of floods }\end{array}$ & $\begin{array}{l}\text { In a lesser extent than the Cantingas } \\
\text { Watershed the forest cover in the } \\
\text { Panangcalan Watershed reduces runoff and } \\
\text { the incidence of most floods }\end{array}$ \\
\hline Siltation mitigation & $\begin{array}{l}\text { The root matrix of the existing vegetation } \\
\text { and the characteristics of the watershed } \\
\text { reduce the rates of soil erosion and } \\
\text { therefore the amount of sediments reaching } \\
\text { the natural waterways }\end{array}$ & $\begin{array}{l}\text { The root matrix of the existing vegetation } \\
\text { and the characteristics of the watershed } \\
\text { reduce the rates of soil erosion and } \\
\text { therefore the amount of sediments reaching } \\
\text { the natural waterways }\end{array}$ \\
\hline \multicolumn{3}{|c|}{ Cultural \& amenity services } \\
\hline Irrigation & $\begin{array}{l}\text { Water has been diverted to irrigate } 560 \text { ha } \\
\text { of rice }\end{array}$ & Non-observed \\
\hline Recreation & $\begin{array}{l}\text { Swimming resorts in lowland areas. In } \\
\text { upland areas activities such as trekking and } \\
\text { swimming are carried out }\end{array}$ & Swimming by local inhabitants \\
\hline
\end{tabular}




\subsubsection{Stakeholders (Sellers, Buyers and Intermediaries) and Institutional Arrangements}

The strategy developed can be considered as a classic example of a PES scheme: 1) the Mangyan Tagabukid Tribe is identified as the service provider or potential seller of ecosystem services, as it influences their quantity and quality; 2) potential buyers are the lowland inhabitants, particularly irrigation communities and urban residents, who benefit directly and indirectly from the watershed services; 3 ) in the past years, environmental degradation has occurred due to improper land use in upland areas of both watersheds; 4) there is a proper political and institutional environment to implement a market-based approach; and 5) there is potential to improve the livelihood of indigenous communities through the payment scheme (WWF/Philippines, n.d.).

\subsubsection{Payment Schemes}

To establish the upper and lower bounds for the PES, it is necessary to estimate the maximum amount of money beneficiaries would pay to maintain the watershed services and the minimum amount of money providers, namely the Mangyan Tagabukid Tribe, would accept to adopt sustainable farming practices (WWF/Philippines, n.d.). The minimum amount of money the Mangyan Tagabukid Tribe would accept at least has to cover the benefits they forgo. The WWF-CARE EPWS project estimated the difference between their declared incomes and their expenditures, as a proxy of the income obtained from illegal resource extraction. In this way, the study estimates that if farmers adopt conservation practices to maintain the availability of watershed services, indigenous households would lose approximately USD 260 per year. Accordingly, this would be the minimum amount of money that beneficiaries should have to pay to service providers (WWF/Philippines, n.d.).

On the other hand, the economic value of the benefits was measured by using the Replacement Cost Method and the Production Function Method. For domestic water users, benefits were measured by estimating the cost domestic users would incur to purchase drinking water. Based on this measurement, an average family of five would have to pay USD 12.68 per month or USD 152 per year to purchase their own drinking water (WWF/Philippines, n.d.). For irrigation farmers, the Production Function Approach was used. If the current soil erosion rate continues, farmers will have to pay to remove silt from canals and they will experience reduced yield as less water reaches their farms. But, if soil conservation measures are put into practice in upland areas, less sediment would reach the waterways, increasing the yields and income of rice farmers. Based on the study from the WWF-CARE EPWS project, the monetary gain from the reduction of the erosion is estimated to be 20 sacks per year, or USD 11.50 per month (USD 138 per year) if the expenses for desilting are deducted (WWF/Philippines, n.d.).

The WWF/Philippines and the LGU of San Fernando have collected USD 16700 (PhP $700000 @ 41.96$ USD = $\mathrm{PhP}$ 1.00) to establish the Cantingas Watershed Fund to be used by the Mangyan Tagabukid to finance the Ancestral Domain Management Plan. The Plan includes the establishment of forest nurseries, tree planting and forest patrols. Likewise, in 2009 the WWF/Philippines and the LGU of San Fernando drafted an ordinance for a water levy. This is in addition to the water fee of USD 0.36 (PhP 15) per month that is charged to the household beneficiaries of the Panangcalan watershed to avail of the waterworks system (Villamor \& Lasco, 2009).

\subsection{Baticulan Watershed}

\subsubsection{Local Conditions and Driving Factors for PES Schemes}

The Baticulan Watershed is located in central Philippines within the boundary of San Carlos City (Villamor \& Lasco, 2007). It has a total area of 428 hectares, with around 500 inhabitants, who are mostly engaged in agriculture (Catacutan et al., 2010). The watershed provides several ecosystem services that benefit different stakeholders at different scales. Households, which include the domestic water users, industrial firms and small-scale farmers, use the clean and regular water from the watershed for domestic or agricultural purposes. The existing forest cover in past years has prevented soil erosion and mitigated extreme weather in the area (Villamor \& Lasco, 2007).

Only $5 \%$ of the existing forest currently remains, and environmental problems abound, for instance, the loss of biodiversity, soil erosion, flooding and loss of soil fertility (Villamor \& Lasco, 2007; San Carlos Development Board [SCDB], 2005; Catacutan et al., 2010). The diversification of agriculture is low, increasing the poverty of local communities. Soil erosion in the watershed has lowered soil fertility and thus affected the productivity of land. The river that runs through San Carlos City has transported the eroded soil to its mouth, where a delta has formed, that in turn has caused local flooding. Furthermore, the land's water storage capacity has decreased leading to the water shortages that have been felt during the summer season (SCDB, 2005).

Because the provision of watershed services has been threatened, the San Carlos City government and citizens became aware of the importance of maintaining the ecological integrity of the watershed, and developed a PES 
scheme that involves upland communities and private land owners (Catacutan et al., 2010; Villamor \& Lasco, 2007). Through the Water City Ordinance No. 37 Series of 2004 "An ordinance regulating the operation of the City Waterworks of the City of San Carlos Negros Occidental and creating the Watershed Development and Protection Fund, and for other related purposes", a special levy was implemented. Under the new ordinance, a special levy was created, for which an environmental fee of PhP 0.75 (USD 0.017) is charged on every cubic metre of water billed. The amount collected for at least 15 years is then transferred to the Watershed Development and Environmental Protection Fund. It is used to address the impacts on the environment, and therefore to restore the structure of the watershed and the services it provides (Villamor \& Lasco, 2007; SCDB, 2005). The basic principle behind the levy is that the price of water should include an environmental rate for which the negative externalities of water extraction are internalized in the market in order to contribute to the sustainable and efficient use of the resource (Villamor \& Lasco, 2007).

\subsubsection{Stakeholders (Sellers, Buyers and Intermediaries) and Institutional Arrangements}

The SCDB is responsible for watershed rehabilitation. Using the money collected through the water levy, the SCDB provides a multi-year watershed rehabilitation and conservation plan. As part of the plan, the different stakeholders are able to negotiate a beneficial output to ensure sufficient watershed services (Villamor \& Lasco, 2007). Thus, the SCDB acts as an intermediary between the service providers (mostly the private landowners) and the beneficiaries or buyers of the ecosystem services, and implements mechanisms to allocate the resources for watershed conservation (Catacutan et al., 2010).

\subsubsection{Payment Schemes}

The project allocates the money collected through the levy to private landowners for reforestation, and thus, watershed conservation (SCDB, 2005). Upland communities, the tenants of private lands, are also involved in the implementation of the project. They are hired by the landowner for a period of three years to plant and maintain the trees (Villamor \& Lasco, 2007). Furthermore, upland people can bargain with the landowner to use a portion of the land to cultivate their own cash crops (Catacutan et al., 2010). The implementation of agroforestry measures is thought to have other positive impacts on the landowner and the upland communities. Due to the high demand for fuel wood, a good market for wood harvesting could be expected. The fuel wood could be sold by the landowner to repay the "Watershed Development and Environmental Protection Fund" (Catacutan et al., 2010). The SCDB provides technical assistance to farmers and, mainly, to private landowners for agroforestry livelihood activities combined with agricultural cropping systems (Villamor \& Lasco, 2007). The ultimate goal is to reforest $40 \%$ of the Baticulan watershed area (SCDB, 2005).

\section{Emerging Lessons from Payment for Watershed Services in the Philippines}

The four case studies described in this paper vary based on their degree of PES implementation, the services traded, the rewards or payments, the degree of awareness of providers and beneficiaries of the ecosystem services, and the legal and institutional framework to support their implementation (Table 3).

The Bakun, Maasin, Baticulan and Sibuyan watersheds do not fully satisfy the five criteria mentioned by Wunder (2005). The only criteria met are that the ecosystem services are demanded by buyers; and the provision and maintenance of the ecosystem services should be made by the service providers. PES schemes are characterized by ill-defined ecosystem services and incomplete information on the link between land use and ecosystem service provision. Moreover, in most cases, government and institutions play a crucial role in the process of establishing PES (Vatn, 2010; Corbera et al., 2007). Understanding how the institutional structures facilitate present cooperation is important for the success of any current and future schemes (Vatn, 2010; Corbera et al., 2007; Landell-Mills \& Porras, 2002). Our discussion focus on the role of institutions and how they affect the PES schemes in terms of meeting the most difficult criteria: the voluntary transaction between providers and buyers; the quantification of the current and potential availability of the ecosystem services, and conditionality in payments. 
Table 3. Summary of the characteristics of the four PES schemes

\begin{tabular}{|c|c|c|c|c|c|}
\hline $\begin{array}{l}\text { Targeted/Provided } \\
\text { Service }\end{array}$ & $\begin{array}{l}\text { Supplier/Service } \\
\text { Provider }\end{array}$ & Buyer & $\begin{array}{l}\text { Values for } \\
\text { Environmental } \\
\text { Services }\end{array}$ & Intermediaries & Payment Scheme \\
\hline \multicolumn{6}{|l|}{ Bakun Watershed } \\
\hline $\begin{array}{l}\text { Water quantity } \\
\text { and water flow } \\
\text { regulation }\end{array}$ & $\begin{array}{l}\text { Upland people } \\
\text { (Indigenous } \\
\text { communities) }\end{array}$ & $\begin{array}{l}\text { Hydropower } \\
\text { companies }\end{array}$ & $\begin{array}{l}\text { Protection of } \\
\text { the watershed } \\
\text { in order to } \\
\text { maintain the } \\
\text { availability of } \\
\text { water for } \\
\text { hydropower } \\
\text { generation }\end{array}$ & $\begin{array}{l}\text { Local } \\
\text { government, } \\
\text { RUPES } \\
\text { (ICRAF) }\end{array}$ & $\begin{array}{l}\text { Cash and in kind } \\
\text { payments }\end{array}$ \\
\hline
\end{tabular}

\begin{tabular}{|c|c|c|c|c|c|}
\hline \multicolumn{6}{|l|}{ Maasin Watershed } \\
\hline $\begin{array}{l}\text { Water supply for } \\
\text { domestic } \\
\text { consumption; } \\
\text { water supply for } \\
\text { irrigation and } \\
\text { wells }\end{array}$ & $\begin{array}{l}\text { Upland people } \\
\text { mostly engaged } \\
\text { in agricultural } \\
\text { activities }\end{array}$ & $\begin{array}{l}\text { Residents of } \\
\text { Ilolio City } \\
\text { and } \\
\text { households } \\
\text { along the } \\
\text { watershed }\end{array}$ & $\begin{array}{l}\text { Protection of } \\
\text { the watershed } \\
\text { in order to } \\
\text { maintain the } \\
\text { availability of } \\
\text { the main } \\
\text { ecosystem } \\
\text { services } \\
\text { provided by it }\end{array}$ & $\begin{array}{l}\text { Local } \\
\text { government } \\
\text { and Iloilo } \\
\text { Watershed } \\
\text { Management } \\
\text { Council }\end{array}$ & $\begin{array}{l}\text { Upland communities } \\
\text { were "rewarded" with } \\
\text { labour's wages for } \\
\text { reforestation and land } \\
\text { rehabilitation. } \\
\text { Likewise the building } \\
\text { capacity of upland } \\
\text { communities and the } \\
\text { cooperative } \\
\text { endeavours of the } \\
\text { members were } \\
\text { supported. } \\
\text { Furthermore, upland } \\
\text { communities received } \\
\text { technical assistance } \\
\text { by DENR }\end{array}$ \\
\hline
\end{tabular}

Sibuyan Watershed

\begin{tabular}{|c|c|c|c|c|}
\hline $\begin{array}{l}\text { Water quality and } \\
\text { erosion control }\end{array}$ & $\begin{array}{l}\text { The Mangyan } \\
\text { Tagabukid } \\
\text { Indigenous } \\
\text { Tribe }\end{array}$ & $\begin{array}{l}\text { Farmers and } \\
\text { water urban } \\
\text { consumers }\end{array}$ & $\begin{array}{l}\text { Improve water } \\
\text { quality and } \\
\text { reduce the } \\
\text { amount of } \\
\text { sediments in } \\
\text { the streams }\end{array}$ & $\begin{array}{l}\text { Payments collected } \\
\text { through a water levy }\end{array}$ \\
\hline
\end{tabular}

\begin{tabular}{|c|c|c|c|c|c|}
\hline \multicolumn{6}{|c|}{ Baticulan Watershed } \\
\hline $\begin{array}{l}\text { Watershed } \\
\text { services }\end{array}$ & $\begin{array}{l}\text { All land owners, } \\
\text { claimants, or } \\
\text { settlers } \\
\text { occupying and } \\
\text { performing } \\
\text { marginal } \\
\text { farming in areas } \\
\text { identified as } \\
\text { forest lands }\end{array}$ & $\begin{array}{l}\text { Households, } \\
\text { which } \\
\text { include the } \\
\text { domestic } \\
\text { water users, } \\
\text { industrial } \\
\text { firms and } \\
\text { small-scale } \\
\text { farmers }\end{array}$ & $\begin{array}{l}\text { Watershed } \\
\text { conservation } \\
\text { and } \\
\text { rehabilitation }\end{array}$ & $\begin{array}{l}\text { San Carlos } \\
\text { Development } \\
\text { Board } \\
\text { (SCDB) }\end{array}$ & $\begin{array}{l}\text { Special levy of PHP } \\
0.75 \text { is charged on } \\
\text { every cubic metre of } \\
\text { water billed. About } \\
80 \% \text { of the budget for } \\
\text { forest establishment is } \\
\text { paid directly to the } \\
\text { service providers. }\end{array}$ \\
\hline
\end{tabular}

\subsection{Voluntary Transaction between Providers and Buyers}

Engel et al. (2008) made a distinction between the different buyers that can operate in a PES scheme. The proposed and implemented schemes in Sibuyan, Maasin and Baticulan can be defined as "government- financed" PES. Since common watershed services are public goods, local governmental institutions, acting on behalf of 
society, are intermediaries between service providers and buyers. This kind of project, as Engel et al. (2008) argue, might be more cost-effective as the result of lower transaction costs. Likewise, in PES project aiming to protect and conserve ecosystem services with the characteristics of public goods, a government-financed program would be more effective than a user-financed one. As Engel et al. (2008) state, a government financed design would help to reduce the problem of free riding caused by the non-excludability of some services and therefore could lead to a better efficiency of the project.

The Bakun case, on the other hand, desires a user-financed scheme. Intermediaries are in charge of collecting the payments from the service beneficiaries to allocate the money in watershed protection and poverty alleviation. The MOAs between the hydropower companies and the LGU needs to be revised and the intermediaries of the RUPES project will try to bring together the service providers and beneficiaries to increase the bargaining power of upland communities.

Also, Grieg-Gran et al. (2005) noted that the bargaining process between service providers and buyers of the ecosystem service should lead to the clear establishment of roles and responsibilities of the different stakeholders. The implementation of PES schemes requires the active involvement of governmental and non-governmental organizations. The Maasin watershed experience demonstrated that institutions are crucial factors in the success or failure of a PES scheme. As Vatn (2010) and Kosoy et al. (2007) pointed out that most PES cases depend strongly on government and community engagement, and thus cannot be considered as voluntary market transactions e.g. water users are not even aware of paying higher water fees for PES (as cited from Muradian et al., 2010). This is why there is a need to instill high level of awareness to both the service providers (upland communities) and buyers (lowland and urban water users) on the watershed-water connection and the objectives of the scheme. A case in point is the social capital that was formed in the efforts to protect the Maasin watershed harnessed through the continuing information, education and communication (IEC) program carried out by Kahublagan Sang Panimalay Foundation. In the Bakun watershed - the people are actively involved, pushed largely by the RUPES project and LGU support. In the Sibuyan and Baticulan cases - through the active involvement of LGUs, watershed management plan and funds have been established and enhanced awareness of the communities. Local government agencies (as intermediaries) play an important role in the IEC programs of the different stakeholders involved. Organizations such as the Bakun Indigenous Tribes Organization in Bakun and the local Kahublagan Sang Panimalay Foundation in Maasin have promoted the participation of upland communities as key elements of the schemes.

The local government is in a unique position to develop a comprehensive plan, negotiate with stakeholders, create the most appropriate payment scheme, and develop a sustainable ecosystem services provision strategy. Given the number of stakeholders' usually involved and competing interests, a more effective PES scheme can be achieved using shared resources and through the development of a collaborative agreement (including water users, hydropower companies, NGOs, people's organization and local government agencies).

\subsection{Quantification of the Current and Potential Availability of the Ecosystem Services}

Generally, PES schemes face the challenge of having limited knowledge and capacity to accurately characterize the interactions between land use and ecosystem service provision (Muradian et al., 2010; Norgaard, 2010; Fisher et al., 2010). This is probably the most critical technical challenge in the PES schemes owing to the complexity, scale and content-dependent nature of the hydrological functions (Kosoy et al., 2006). Many PES at the watershed level are based on the conventional wisdom that there is a positive relationship between forest cover and water quantity and quality, a shared belief that sometimes is not supported by hydrological evidence (Kosoy et al., 2007). As a precautionary strategy to deal with uncertainty and incomplete information, practitioners base their decisions on assumptions about the relationship between the promoted land use, the impact on the provision of ecosystem services and finally the induced changes in welfare (Muradian et al., 2010).

The lack of understanding of the link between land use and service provision might have led to failure in the Maasin experience as there has been observed reduction in the water supply especially during the dry months. Beneficiaries (water consumers) were no longer happy with the outcome of the project due to a significant decrease in stream flow after a reforestation program. This clearly demonstrates that PES schemes based on myths or presumed relationships between land use and watershed services might lead to lower efficiency. Whether or not forests reduce flooding and increase water flow has not been established in most of the sites. In Bakun and Baticulan, forests and agroforestry systems are assumed to slow runoff, increase water flow in the dry season, increase total annual water flow, and reduce flooding and erosion. These myths or presumptions however are not always true. Although vegetation cover and soil management practices in agriculture highly influence the 
rates of discharge and recharge in water bodies, the storage capacity, and the infiltration and evapo-transpiration of water, ecosystem services such as water quantity, water quality, and water regulation are site-specific (Wünscher et al., 2008). According to Tognetti et al. (2005) and Pagiola (2003), the role of forests in regulating water flow is still unclear and depends on numerous site-specific factors. For instance, forests decrease total annual water flow instead of increasing it, as a result of higher evapo-transpiration rates. Furthermore, while forests reduce small scale floods, this is not always true for the large scale. Finally, the reduction of erosion depends on how deforested areas are used.

In the absence of data regarding ecosystem services and the role of alternative land uses in service provision, Rapid Hydrological Assessments were carried out in the Bakun and Baticulan watersheds. These rough calculations are being used now but should be improved over time as more information is acquired. It is essential to strengthen the science of the PES schemes in Bakun and Baticulan to raise awareness about the importance of maintaining the ecological integrity of upland areas as service providing units of ecosystem services. Additionally, if the induced land use changes do not produce the desired availability of ecosystem services, payments will not be efficiently allocated to those important service areas, but will instead be allocated guided by political motives or expediency.

Local decision makers are often faced with no data on land use impacts on water resources, and generating this data can be costly. In the case of Maasin for example, the appropriate method for restoration of the vegetative cover (i.e. use of fast growing exotic species or use of endemic species) was a challenge. There is also a gap on the technical skills with regards to the appropriate farming practices that will protect the soil and improve water flow in Bakun and Baticulan. The successful implementation of PES schemes will thus require building the technical capacity of the local government agencies and stakeholders to raise understanding among buyers and service providers on the dynamic relationship of land use and watershed functions. This will help ensure effective reforestation programs and sustained provision of ecosystem services.

\subsection{Conditionality}

The deficit of robust scientific data about ecosystem services coupled with a deficit in fulfillment of the fifth criterion mentioned by Wunder (2005), "the payment should be made only with the condition that the provider secure the flow of the ecosystem service through time, namely additionality must be proved", might lower the environmental efficiency of the PES schemes described in this paper. Because the long term permanence of a PES scheme largely depends on its capacity to demonstrate additionality, the roles and responsibilities of the different parties involved should be clearly established. The Baticulan Project partially achieves this. Providers have to undergo a series of orientations and meetings as part of the community organizing and capacity building phase of the project. Likewise, in the reforestation stage, they have to submit a farm work plan that must be approved. In case the requirements are not met by service providers or beneficiaries, penalties for non-compliance are put in place. Nevertheless, as Corbera et al. (2009) note, the lack of conditionality is often common in "government-financed" schemes. Also, Wunder (2007) reviewed cases from Bolivia and Vietnam and found that there is loose monitoring of provision of payments, thus failing to meet the conditionality criteria. This is also true in other cases (Muradian et al., 2010).

It has been established above that it is often difficult to measure the baseline and the process might raise transaction costs. According to Padilla et al. (2005), high transaction costs arise from the need to involve many stakeholders with different interests, costly information requirements and stakeholder consultations and negotiations. Taking this into account, it is easier to understand why the role of local governments and NGOs are so crucial in PES schemes particularly in strengthening cooperation among stakeholders and establishing a more efficient PES scheme. As shown in the case studies, city councils like the SCDB in Baticulan and LGU in Sibuyan are much easier to raise the necessary funding through water levy and the arrangements with the service providers and buyers are simplified through the watershed fund. However, in the Bakun experience, rewards are not being channeled to service providers and the funds collected from the hydropower companies has not been allocated for watershed conservation. Since the distribution of funds has not been clearly established, local governments invest the money in communities that are actually not providing the services. Unclear institutional set-up and goals can cause the PES scheme intended for watershed services provision to work inefficiently. Therefore, institutional procedures and guidelines particularly the roles and responsibilities, payment schemes, monitoring and implementation procedures, need to be clearly defined and coordinated, across all the institutions involved. The local government plays a vital role in the coordination and establishment of a functional institutional set up to support the PES scheme. 


\section{Conclusions and Recommendations}

The implementation of PES in developing countries like the Philippines is still in its infancy. Early experiences are encouraging but significant roadblocks remain as we have shown in the four cases we have reviewed. There is clearly interest amongst national and local stakeholders in finding ways to sustainably finance watershed conservation and rehabilitation initiatives. This is shown in the rise of pilot PES schemes in many parts of the country.

In this paper, we have argued that PES as defined by Wunder is in practice difficult to attain, largely due to the huge lack of knowledge on quantifying ecosystem services and in cases possible would be too costly and time consuming. PES programs are mostly characterized by incomplete information, lack of technical capacities and high monitoring costs. In the case studies presented in this paper, most PES are based on myths or presumed relationships between land use and watershed services. Also, unclear institutional set-up and goals can cause the PES scheme intended for watershed services provision to work inefficiently.

While the Coasean approach to PES does not give enough attention to the role of institutions (Muradian et al., 2010), we argued that institutions may enable or hinder the successful implementation of PES. The role of the local government as intermediaries is crucial in the process of establishing PES more particularly in the information dissemination and education of the key stakeholders. The case studies also showed how PES programs are actually reinforced by the presence of non-government organizations like the Bakun Indigenous Tribes Organization in Bakun and the local Kahublagan Sang Panimalay Foundation in Maasin which promoted the social strength of upland communities.

In the four case studies, some key issues have been identified that may be considered in the implementation of existing and new PES schemes. First, PES schemes need to take into account the institutional and social conditions prevailing in the area. The interventions needed to a more efficient PES usually entail the degree of coordination between stakeholders and strategic allocation of roles and responsibilities among institutions involved. Second, it is important to understand the effect of uncertainty due to the limited knowledge about the interaction between ecosystem properties and provision of services in the decision-making process and the design of the PES scheme. Lastly, current experiences need to be constantly revised and improved and new efforts need to be explored in order to sustain the flow of watershed services over time as a basis for sustainable development.

\section{References}

Alpízar, F., \& Madrigal, R. (2008). Constructing payment schemes for ecosystem services at the local level: methodological approach and some lessons learned. Economics and Conservation In The Tropics: A Strategic Dialogue. Retrieved from http://www.rff.org/Documents/08_Tropics_Conference/Tropics_Conference_Papers/Tropics_Conference_ Alpizar_Madrigal_Payment_Schemes.pdf

Arocena-Francisco, H. (2002). Environmental service "payments": Experiences, constraints and potential in the Philippines. Developing Mechanisms For Rewarding The Upland Poor In Asia For Environmental Services They Provide. Puncak, Indonesia: World Agroforestry Centre (ICRAF).

Balmford, A., Bruner, A., Cooper, P., Costanza, R., Farber, S., Green, R. E., ... Turner, R. K. (2002). Economic reasons for conserving wild nature. Retrieved from http://www.envirosecurity.org/conference/working/ReasonsConservWildNature.pdf

Bennagen, M. E., Indab, A., Amponin, A., Cruz, R., Folledo, R., Van Beukering, P. J. H., ... De Jong, J. (2006). Designing payments for watershed protection services of Philippine upland dwellers. Retrieved from http://www.prem-online.org/archive/5/doc/PWS\%20Philippines\%20final\%20report.pdf

Catacutan, D. C., Villamor, G., \& Piñon, C. D. (2010). Local government-led PES for watershed protection: Cases from the Philippines. Mountain Forum Bulletin. Volume X, Issue 1. Retrieved from http://www.mtnforum.org/en/content/local-government-led-pes-watershed-protection-cases-philippines

Corbera, E., Soberanis, C. G., \& Brown, K. (2009). Institutional dimensions of payments for ecosystem services: An analysis of Mexico's Carbon Forestry Programme. Ecological Economics, 68, 743-761. http://dx.doi.org/10.1016/j.ecolecon.2008.06.008

Chokkalingam, U., Carandang, A. P., Pulhin, J. M., Lasco, R. D., Peras, R. J. J., \& Toma, T. (2006). One century of forest rehabilitation in the Philippines: Approaches, outcomes and lessons. ISBN 979-24-4643-5.Bogor, Indonesia: Center For International Forestry Research (CIFOR). 
De Groot, R., De Wit, M., Brown Gaddis, E., Kousky, C., Mcghee, W., \& Young, M. D. (2007). Chapter 32: Making restoration work: Financial mechanisms. Restoring Natural Capital: Science, Business, and Practice. Society for Ecological Restoration International. Island Press.

Engel, S., Pagiola, S., \& Wunder, S. (2008). Designing payments for environmental services in theory and practice: An overview of the issues. Ecological Economics, 65, 663-674. http://dx.doi.org/10.1016/j.ecolecon.2008.03.011

Francisco, H., \& Rola, A. C. (2004). Realities of watershed management in the Philippines: Synthesis of case studies. Discussion Paper Series No. 2004-24

International Union for Conservation of Nature. (2000). Financing protected areas:Guidelines for protected area managers. World Commision on Protected Areas (WCPA). ISBN 2-8317-0544-4

Kosoy, N., \& Corbera, E. (2010). Payments for ecosystem services as commodity fetishism. Ecological Economics, 69, 1228-1236. http://dx.doi.org/10.1016/j.ecolecon.2009.11.002

Kosoy, N., Martinez-Tuna, M., Muradian, R., \& Martinez-Alier, J. (2007). Payments for environmental services in watersheds: Insights from a comparative study of three cases in Central America. Ecological Economics, 61, 446-455. http://dx.doi.org/10.1016/j.ecolecon.2006.03.016

Lasco, R. D., Evangelista, R., \& Pulhin, F. B. (2010). Potential of community-based forest management (CBFM) to mitigate climate change in the Philippines. Small Scale Forestry Journal, 9, 429-443. http://dx.doi.org/10.1007/s11842-010-9132-0

Leimona, B., Villamor, G., Noordwijk, M. V., Fauzi, A., \& Utaira, R. (2007). Developing mechanisms to reward the upland poor in Asia for environmental services that they provide (RUPES). Bogor, Indonesia: World Agroforestry Centre (ICRAF).

Millenium Ecosystem Assessment (MA). (2005). Ecosystems and human well-being: A framework for assessment. Island Press. Retrieved from http://www.millenniumassessment.org/documents/document.356.aspx.pdf

Muradian, R., Corbera, E., Pascual, U., Kosoy, N., \& May, P. H. (2010). Reconciling theory and practice: An alternative conceptual framework for understanding payments for environmental services. Ecological Economics, 69, 1202-1208. http://dx.doi.org/10.1016/j.ecolecon.2009.11.002

Padilla, J. E., Tongson, E., \& R Lasco, Ed. (2006). PES: Sustainable Financing For Conservation And Development: Proceedings From The National Workshop On Payments For Environmental Services: Direct Incentives For Biodiversity Conservation And Poverty Alleviation, 2005 Manila, Philippines. Wwf, Icraf, Reecs, Up-Cids, Uplb-Enfor, Care, 103-115.

Pagiola, S. (2003). Can programs of payments for environmental services help preserve wildlife? Convention on international trade in endangered species of wild fauna and flora: Workshop on economic incentives and trade policies. Geneva. Retrieved from http://www.cites.org/eng/prog/economics/ppt/World_Bank.pdf

Pagiola, S., Arcenas, A., \& Platais, G. (2005). Can payments for environmental services help reduce poverty? An exploration of the issues and the evidence to date from Latin America. World Development, 33, 237-253. http://dx.doi.org/10.1016/j.worlddev.2004.07.011

Pagiola, S., Ramírez, E., Gobbi, J., De Haan, C., Ibrahim, M., Murgueitio, E., \& Ruíz, J. P. (2007). Paying for the environmental services of silvopastoral practices in Nicaragua. Ecological Economics, 64, 374-385. http://dx.doi.org/10.1016/j.ecolecon.2007.04.014

Pascual, U., Muradian R., Rodriguez, L., \& Duraiappah A. (2010). Ecological Economics, 69, 1202-1208. http://dx.doi.org/10.1016/j.ecolecon.2009.11.002

Porras, I., \& Neves, N. (2006). Markets for watershed services - Country profile: Philippines -Maasin Watershed. International Institute For Environment And Development (IIED).

Salas, J. (2004). Case study of the Maasin Watershed: Analyzing the role of institutions in a watershed conflict. Rewarding Upland Poor fo Environmental Services (RUPES) Project. World Agroforestry Centre (ICRAF).

Salas, J. (2005). Environmental Service Payments For The Maasin Watershed A Case Study. In: Padilla, J. E., Tongson, E And R Lasco, Ed. PES: Sustainable Financing For Conservation And Development: Proceedings From The National Workshop On Payments For Environmental Services: Direct Incentives For Biodiversity Conservation And Poverty Alleviation.Manila, Philippines. WWF, ICRAF, REECS, UP-CIDS, UPLB-ENFOR, CARE, 103-115. 
San Carlos Development Board. (2005). San Carlos Watershed Management and Development Project.

Swallow, B., Leimona, B., Yatich, T., \& Velarde, S. J. (2010). The conditions for functional mechanisms of compensation and reward for environmental services. Ecology and Society, 15, 6. Retrieved from http://www.ecologyandsociety.org/vol15/iss4/art6/

Tognetti, S. S., Aylward, B., \& Mendoza, G. (2005). Markets for Watershed Services. In Anderson M. Ed. Encyclopedia of Hydrological Sciences. John Wiley \& Sons, Ltd.

Turner, R. K., Van Den Bergh, J. C. J. M., Söderqvist, T., Barendregt, A., Van Der Straaten, J., Maltby, E., \& Van Ierland, E. C. (2000). Ecological-economic analysis of wetlands: Scientific integration for management and policy. Ecological Economics, 35, 7-23. http://dx.doi.org/10.1016/S0921-8009(00)00164-6

Vatn, A. (2010). An institutional analysis of payments for environmental services. Ecological Economics, 69, 1245-1252. http://dx.doi.org/10.1016/j.ecolecon.2009.11.002

Villamor, G. B., Banatao, A., Beta-A. A., \& Lasco, R. D. (2007). Watershed services agreements: An analysis of benefits towards a pro-poor reward mechanism in Bakun, Philippines. World Agroforestry Centre (ICRAF).

Villamor, G. B., \& Lasco, R. D. (2006). RUPES: A bright future for Philippine upland poor. Towards sustainable livelihoods and ecosystems in mountains regions. Chiang Mai, Thailand.

Villamor, G. B., \& Lasco, R. D. (2007). Water levy as financing scheme for watershed protection - a city government initiative to rehabilitate the Baticulan Watershed, Philippines. Proceedings of the 1st International Forum on Water Governance in Asia. Bangkok, Thailand. Retrieved from www.worldagroforestry.org/downloads/publications/.../pp07182.pdf

Villamor, G. B., \& Lasco, R. D. (2009). Rewarding upland people for forest conservation: Lessons learned from case studies in the Philippines. Journal of Sustainable Forestry, 28, 304-321. http://dx.doi.org/10.1080/10549810902791499

Wünscher, T., Engel, S., \& Wunder, S. (2008). Spatial targeting of payments for environmental services: A tool for boosting conservation benefits. Ecological Economics, 65, 822-833. http://dx.doi.org/10.1016/j.ecolecon.2007.11.014

Wunder, S. (2005). Payments for environmental services: Some nuts and bolts. CIFOR Occasional Paper No. 42. ISSN 0854-9818

Wunder, S. (2007). The Efficiency of payments for environmental services in tropical conservation. Conservation Biology, 21, 48-58. Retrieved from http://www.readinglists.manchester.ac.uk/link?url=http\%3A\%2F\%2Fdx.doi.org\%2F10.1111\%2Fj.1523-17 39.2006.00559.x

World Agroforestry Centre, Philippines. (2006). Terminal Report. The Bakun Watersheds of Northern Philippines: Testing the Rewards and Reward Mechanisms that Benefit Its Upland Dwellers for the Watershed Services They Provide. Los Baños, Philippines. ICRAF.

World Agroforestry Centre Philippines. (2007). Final draft: Assessment of the current benefits provided by the hydroelectric power companies to Bakun municipality: The case of Bakun, Benguet. ICRAF Los Baños, Philippines.

World Agroforestry Centre. (2008). The Bakun Watershed of Northern Philippines: Testing the Rewards and Reward Mechanisms to Benefit its Upland Dwellers for the Watershed Services They Provide. Rewarding Upland Poor for Environmental Services. ICRAF, Los Baños, Philippines.

World Wildlife Fund Philippines.(n.d.). Sibuyan Project.Manila, Philippines: World Wildlife Fund for Nature, WWF.

World Wildlife Fund. (2006). Payments for Environmental Services - An equitable approach for reducing poverty and conserving nature. World Wildlife Fund for Nature, WWF. 